\title{
SOBRE EL ESTADO ACTUAL DEL DEBATE EN TORNO A LA PUNIBILIDAD ${ }^{1}$
}

\author{
Octavio García Pérez ${ }^{2}$
}

Resumen: El objeto de este trabajo es estudiar el debate sobre la punibilidad que se ha producido en los últimos veinte años. Se reconoce que más allá de la culpabilidad hay espacio para circunstancias basadas en consideraciones de utilidad. Pero todavía se discute si estos elementos deben pertenecer a una categoría o a varias. Se intenta justificar que hay buenas razones para unificar todas las circunstancias situadas más allá de la culpabilidad en una categoría, la punibilidad.

Palabras clave: punibilidad, teoría jurídica del delito, causas de exclusión de la pena, proceso penal, momento constitutivo del delito.

Recibido: septiembre 2019. Aceptado: noviembre 2019

1 Trabajo realizado en el marco del proyecto de investigación financiado por el Ministerio de Innovación, Ciencia y Universidades, DER2015-67512-P, sobre la influencia de la jurisprudencia del Tribunal Europeo de Derechos Humanos en el Derecho interno.

2 Catedrático de Derecho Penal. ORCID ID: https://orcid.org/0000-0001$\underline{6881-6522}$

Departamento de Derecho Público. Facultad de Derecho de la Universidad de Málaga. Bulevar Louis Pasteur, 26, 29071 Málaga. Email: ogarcia@uma.es 


\title{
The current state of the discussion \\ on "punishability"
}

\begin{abstract}
The purpose of this paper is to study the academic debate on the criminal-law category "punishability" held during the last twenty years.Although it is acknowledged that utility-based grounds can find a place beyond the category "culpability", it is still discussed wether they should be integrated into one or several categories. Solid arguments in favour of merging all those grounds into a single category, namely "punishability", are presented and defended.
\end{abstract}

Keywords: punishability, Analytical concept of criminal offence, grounds for exclusion of punishment, criminal proceedings, constitutive moment of the criminal offence.

\section{Introducción}

El objeto de este trabajo es efectuar un análisis del debate sobre la necesidad o no de configurar una categoría del delito ubicada más allá de lo injusto culpable, pero limitado a los últimos veinte años. Como es sabido, se ha discutido hasta la saciedad la conveniencia de admitir un elemento del delito que se situaría tras la culpabilidad, donde pese a la rotundidad de algunas conclusiones de los detractores de la admisión de una nueva categoría, lo cierto es que el debate está más vivo que nunca y hasta donde alcanzo a ver cada vez son más los partidarios de asumir su existencia, al menos en nuestro país.

Sin embargo, no se puede olvidar que hay un sector de la doctrina, con cualificados representantes, que con diferentes argumentos rechazan la posibilidad de incluir una nueva categoría del delito, si bien una buena parte de la crítica gira especialmente en torno a la definición de delito y uno de los términos empleados para designar esta supuesta nueva categoría, la punibilidad.

En la primera parte de mi trabajo voy a efectuar un análisis crítico de esta posición, para a continuación centrarme en la posición mayoritaria donde, más allá de la aceptación de la categoría, no deja de haber, al menos en apariencia, profundas 
discrepancias tanto en lo relativo al fundamento como en lo referido a su propio contenido y a la clasificación de sus elementos. En el estudio no solo interesa identificar a grandes rasgos las diversas posiciones, sino los concretos razonamientos que cada autor efectúa con la finalidad de tratar de descubrir en ellos puntos de posible consenso. De ahí que la exposición se detenga en las opiniones de cada uno de los autores. Como intentaré hacer ver, creo que en algunos casos las divergencias son menores o incluso inexistentes.

\section{La punibilidad como una categoría ubicada fuera del ám- bito de la teoría jurídica del delito}

Un sector de la doctrina entiende que la presencia del injusto culpable no es suficiente para imponer una pena, pues en ocasiones se necesitan otras circunstancias que nada tienen que ver con estos elementos, pero, al mismo tiempo, se resalta que no pueden conformar una categoría del delito, si bien los razonamientos varían según los autores.

Morillas Cueva reconoce que, a veces, además de lo injusto culpable y la ausencia de error son necesarios "algunos presupuestos legales que, con carácter adicional se muestran para completar la hipótesis de aquella, es decir, de poder aplicar o no la pena fijada por ley a la correspondiente infracción criminal". Para él, estas circunstancias no se pueden situar al mismo nivel que antijuridicidad y la culpabilidad. Y por ello, añade, "no han de ser integrados a este nivel sistemático de la estructura delictiva, alejándome de tal manera de la tradicional comprensión de la punibilidad como un elemento más del delito" ". Más adelante admite, no obstante, que su postura es cercana a la de quienes reconocen la existencia de la punibilidad como categoría del delito, pues estructura "la punibilidad de manera unitaria cercana a la teoría jurídica del delito, a sus elementos, constitutivos pero

3 Morillas Cueva, L.: Sistema de Derecho penal. Parte General. Dykinson, Madrid, 2018, págs. 325 y s. 
no como uno de ellos sino en todo caso como asociación adicional, en clave de exigencia de pena, sistemáticamente ubicada dentro del estudio del delito, en este caso doloso". Entre sus componentes incluye las condiciones objetivas de punibilidad, las excusas absolutorias y las condiciones de procedibilidad ${ }^{4}$.

Para Manjón-Cabeza la punibilidad constituye una categoría autónoma de los elementos clásicos del delito y que acoge una serie de instituciones que tienen en común la evitación de la pena que correspondería aplicar al delito o su atenuación. Son circunstancias que no afectan a lo injusto culpable sino a la pena. En relación a las excusas absolutorias indica que su concurrencia "no hace que desaparezca el delito -como unidad-, que subsiste, ni sus elementos, que siguen presentes, por más que no se aplique pena. El delito no desaparece, entre otras cosas porque se mantiene la responsabilidad penal por ese hecho para otros intervinientes en el delito no alcanzados por la excusa; éstos siguen siendo intervinientes -autores, coautores o partícipes- en un delito que existe y que no ha desaparecido para nadie, aunque finalmente unos reciban pena, por no existir ninguna razón de oportunidad que indique la conveniencia de lo contrario, y otros queden impunes; todo lo anterior, a la vista de que el principio de accesoriedad exige la existencia de una conducta antijurídica para castigar a los partícipes. Por otro lado -también se ha dicho-, si el delito desapareciera, no cabría considerar la existencia de una conducta antijurídica, ni la posibilidad de repelerla en legítima defensa. Finalmente, sin delito, no sería posible exigir la responsabilidad civil derivada del delito sin una percha de la que colgarla igual o similar a la contenida en el art. 118.1. Son estos efectos, más la no aplicación de la pena para el "dueño" de la excusa, los que determinan la naturaleza jurídica de las excusas. En cuanto su fundamento indica que representan situaciones en las que la pena es innecesaria, "por más que sea merecida, pudiendo ser su aplicación contraproducente (lo que puede observarse en las excusas que se refieren al parentesco) o

4 Morillas Cueva, L.: Sistema. Op. Cit., pág. 733. 
ser recomendable excusarla (por estar ante un comportamiento posterior positivo). Se parte aquí de que hay merecimiento de pena cuando se realiza el injusto culpable, lo que aparece como la condición necesaria para aplicar la pena. Pero la pena merecida puede ser innecesaria o inconveniente; esto es lo que ocurre cuando concurre una excusa absolutoria: la pena merecida deja de ser necesaria porque sus fines pueden actuarse de otra forma que no consista en la imposición de la pena concreta"s.

Los argumentos que ofrece Manjón-Cabeza no resultan concluyentes. En relación a las excusas absolutorias señala que el delito subsiste, puesto que se mantiene la responsabilidad de los demás intervinientes en él. Sin embargo, esto mismo es lo que sucede con la culpabilidad y ello no ha impedido su caracterización como un elemento del delito. En efecto, la concurrencia de una causa de exclusión de la culpabilidad hace desaparecer el delito para aquel en quien concurre, manteniéndose el delito para los demás. Tampoco parece convincente rechazar la admisión de la punibilidad como categoría alegando que las excusas absolutorias harían desaparecer el delito por lo que no habría conducta ilícita y, en consecuencia, no cabría ejercer la legítima defensa. Desde que hay un hecho ilícito, y siempre lo hay en todas las circunstancias que afectan a la punibilidad, ya hay base para la responsabilidad civil. Cuestión diversa es si se puede exigir allí donde no se ha previsto expresamente. En mi opinión, se podría apreciar por analogía, puesto que estamos ante una cuestión de índole civil.

Moreno-Torres Herrera entiende que "la punibilidad constituye una categoría dogmática independiente y autónoma que viene a adjetivar el concepto de delito. No es correcto afirmar que sólo es delito lo que es punible. Por el contrario, la punibilidad es una categoría que no se une a las que conforman el delito, sino que perfila el concepto de delito añadiéndole el

5 Manjón-Cabeza Olmeda, A.: Las excusas absolutorias del derecho español (doctrina y jurisprudencia). Tirant lo Blanch, Valencia, 2014. DOCUMENTO TOL4.705.027 
matiz, básico por lo demás, de que la conducta calificada como delictiva resulta, además, punible. Y dado que, por regla general, una acción típica, antijurídica y realizada de forma culpable es punible, a la punibilidad no se le puede dar el mismo rango que a los elementos del delito". Para que el delito sea punible, además del merecimiento de pena para cuya concurrencia basta con el injusto culpable, se requiere la necesidad de pena. Esta hace referencia a la utilidad o conveniencia político-criminal de la sanción penal. Esto significa que es preciso determinar si "el delito tiene que ser penado por no existir otro medio disponible que sea eficaz y menos aflictivo".

La razón fundamental para rechazar que la punibilidad sea una categoría del delito es que por regla general el injusto culpable es punible, es decir, son pocos los casos donde, concurriendo este, no se va a aplicar una pena. En el fondo con ello lo que se afirma es que, al tratarse de unos elementos residuales, no pueden reclamar un lugar en la teoría del delito como sucede con el injusto culpable. ¿Cabría sostenerse esta idea si se incluyeran circunstancias contempladas en otros códigos penales como la mediación o la pena natural?

Para Bustos resulta imprescindible "diferenciar entre «punibilidad» entendida conceptualmente y «punibilidad» entendida estructuralmente". Desde la perspectiva conceptual "«punible» implica que el hecho se puede penar, lo que constituye una realidad obvia en el caso del delito, pues de por sí todo hecho delictivo es aquél que lleva aparejada una pena... Lo anterior constituye una premisa obvia, que hace reconocer el carácter conceptual de la punibilidad en el seno del delito. Sin embargo, ello no significa todavía que todo hecho punible sea por fuerza hecho penado". Así pues, es punible "toda acción u omisión típica, antijurídica y culpable...Tales características son, en rigor, condicionantes de la punibilidad del hecho: solo

6 Moreno-Torres Herrera, M. R.: “La punibilidad", en Zugaldía Espinar, J. M. (Dir.): Lecciones de Derecho penal. Parte General. $3^{\mathrm{a}}$ ed. Tirant lo Blanch, Valencia, 2016, págs. 165 y s. 
constatadas las anteriores resulta la posibilidad de penar una determinada conducta" 7 .

En su argumentación, si he entendido correctamente, parece haber un salto lógico, pues se dice que está sancionado con pena y, por tanto, es punible, todo hecho típico, antijurídico y culpable. Si ello es así, está claro que no puede haber una categoría ubicada tras la culpabilidad. Pero esto es lo que todavía no ha demostrado. En realidad, su razonamiento parece incurrir en una petición de principio: dado que el delito se agota en lo injusto culpable, está sancionado con pena y, por tanto, es punible, todo hecho típico, antijurídico y culpable. Sin embargo, como vamos a ver, lo que un importante sector de la doctrina argumenta es que justo detrás de la culpabilidad hay otro elemento del delito al que se le llama punibilidad, penalidad, otros presupuestos más allá de lo injusto culpable o necesidad de pena con un contenido propio. Y esto nada tiene que ver con la nota conceptual de delito de ser un hecho punible.

Continúa el autor indicando que "si el comportamiento típico, antijurídico y culpable es presupuesto para la punibilidad, entonces esta no puede configurarse como elemento estructural del delito: tendrá que existir un delito para poderse aplicar una pena. La punibilidad, en definitiva, no es parte estructural del delito, sino consecuencia del mismo". Por tanto, a su juicio, la punibilidad es una nota conceptual, pero no puede constituir un elemento del delito. "No resulta apropiado entonces decir que para que un delito sea punible, tiene que ser punible. Constituiría ello una tautología, o una redundancia, pues se estaría definiendo al delito no ya por los elementos que lo componen sino por sus consecuencias. Dada esta demasía, estamos en disposición de afirmar que la punibilidad es un estadio, independiente al delito, ajeno a los elementos que lo definen. O lo que es lo mismo: el delito existe cuando se coteja que un determinado hecho es típico, antijurídico y culpable. Y a raíz de esto, como consecuen-

7 Bustos Rubio, M.: "Más allá del injusto culpable los presupuestos de la punibilidad", en Estudios penales y criminológicos, nº. 35, 2015, págs. 196 y s. 
cia, se convierte en un hecho susceptible de ser penado (esto es, punible)". No se puede sostener -continúa el autor-que "lo que acompaña al delito (la punibilidad entendida como posibilidad de punición del mismo) sea a la vez consecuencia y elemento configurador del delito mismo. Por ello es correcto afirmar la punibilidad como carácter del delito: este no es más que el hecho punible. Pero estructuralmente no es posible afirmar que la punibilidad sea nota esencial y característica del delito...". A partir de aquí concluye el autor que "La punibilidad es, por tanto, una categoría propia existente, pero en todo caso ajena al delito, comprensiva de un conjunto de elementos que juegan su papel tras la existencia de éste...En definitiva: la punibilidad ... no se mueve en el seno de la teoría tradicional del delito, sino que se encuentra más próxima a la teoría de la pena"s.

Si hubiera una tautología, no habría categoría alguna ni dentro ni fuera del delito. En la medida en que hay unos contenidos que se deben contemplar porque no están abarcados por lo injusto culpable y se consideran necesarios, ya no hay razón alguna para no incluirlos en la teoría del delito sin incurrir en tautología alguna. Sencillamente lo que sucede es que un mismo término "la punibilidad" se utiliza para designar dos aspectos diferentes. Esto no es ninguna novedad. Piénsese, por ejemplo, en el propio término delito que unas veces se ha utilizado en un sentido amplio para designar a todos los hechos sancionados con pena y en otros en uno mucho más restringido para referirse solo a una parte de ellos. Así acontecía cuando el Código penal distinguía entre delitos y faltas. Y lo mismo cabría decir respecto del principio de proporcionalidad que también se suele usar con dos acepciones, una amplia que abarcaría la idoneidad, la necesidad y la proporcionalidad en sentido estricto y uno más restringida que alude solo a la última.

Un último problema que plantea esta concepción es que si el delito es un hecho punible, ahora no lo es, porque el que exista un delito en abstracto no significa que haya pena en abstracto,

8 Bustos Rubio, M.: Más allá del injusto culpable. Op. Cit., págs. 197 y ss. 
puesto que la pena depende ahora de dos realidades el delito y la punibilidad. Por tanto, la pena ahora tiene dos presupuestos el delito y la punibilidad. A mi juicio, ello supone paradójicamente privar al delito de su nota conceptual: es un hecho punible.

La versión más fundada de esta tesis es la ofrecida por Mendes de Carvalho. Esta autora considera que la punibilidad no constituye un elemento del delito y ello pese a reconocer que tiene un contenido propio diverso a lo injusto culpable y que constituye un presupuesto de la pena que estaría integrado por condiciones objetivas de punibilidad y excusas absolutorias. A su juicio no representa una categoría del delito por varias razones. En primer lugar, por el escaso número de circunstancias de esta índole que se contemplan en la legislación penal. No obstante, admite que la moderna legislación penal las está introduciendo cada vez más. Pero, a su juicio, la razón fundamental para el rechazo deriva del hecho de que se trataría de circunstancias basadas en criterios político-criminales, y especialmente relativas a los fines de la pena9. En su concepción del Derecho penal se parte de un "rechazo contundente" de las propuestas metodológicas que pretenden configurar el delito "a partir de y con referencia a la pena". Por ello no puede admitir una categoría del delito que responda a consideraciones relativas a los fines de la pena. En definitiva, es su posición respecto a la función del Derecho penal y de la pena la que le impide reconocer que las condiciones objetivas de punibilidad y las excusas absolutorias puedan integrar una categoría del delito ${ }^{10}$. En su opinión, el principio de subsidiariedad no puede constituir el fundamento

9 Mendes de Carvalho, E.: Punibilidad y delito. Reus, Madrid, 2007, págs. 56 y s. y 467 y s. También recientemente, Bittar, W. B.: A punibilidade no direito penal. Almedina, 2015, págs. 106 y ss, especialmente 115 y ss., considera que la punibilidad es una categoría autónoma, pero no forma parte del delito. Para este autor la eliminación de la punibilidad no afecta a los demás elementos del delito que sigue siendo ilícito, puesto que el delito no encuentra su límite en la punibilidad y mucho menos en la aplicación de la pena. La posibilidad de la punición es posterior al delito y anterior a la aplicación y ejecución de la pena: puede estar entre el delito y la pena.

10 Mendes de Carvalho, E.: Punibilidad. Op. Cit., pág. 467. 
común a todas estas circunstancias. Y ello porque, en su opinión, este principio "supone no una relación de costes-beneficios a través de la imposición de la pena, sino la exigencia de que no sean suficientes las sanciones de los demás sectores del ordenamiento jurídico. ¿Y cuándo no serán suficientes tales sanciones? Cuándo la gravedad de las infracciones desde el punto de vista material, es decir, el desvalor ético-social o cultural -y sólo de modo secundario la rapidez y eficacia de la sanción...-indiquen la necesidad de la intervención penal"11. En su opinión, "la presencia de una condición objetiva de punibilidad o la realización de un comportamiento postdelictivo positivo...no demuestran un menor menoscabo del bien jurídico y no intervienen sobre la intensidad de la lesión del mismo. Además, tampoco pueden demostrar una menor gravedad de las infracciones desde el punto de vista material. Por consiguiente, si se concibe el principio de subsidiariedad como la exigencia de que la intervención penal se circunscriba a los ilícitos más graves, el contenido del mismo no puede ofrecer el fundamento de las condiciones objetivas de punibilidad, puesto que las exenciones de pena o las atenuantes que producen la ausencia o presencia de las mismas no son una expresión de la menor gravedad de la infracción"12.

Con esta concepción, fragmentariedad y subsidiariedad vienen a coincidir. No solo es que el Derecho penal pueda ocuparse de los ataques más relevantes a los bienes jurídicos más importantes, sino que debe hacerlo. Allí donde se produce una intensa afección a un objeto de tutela relevante, el Derecho penal está obligado a intervenir, o lo que es lo mismo, en tales hipótesis hay siempre tanto merecimiento como necesidad de pena. En efecto, desde una teoría absoluta esto es así. En este sentido señala la autora que "sólo la idea de pena justa y proporcionada a la gravedad de lo injusto y la culpabilidad, es decir, la idea de la retribución, puede operar como un límite al ius puniendi estatal"13. Desde esta óptica, solo cabría objetar que no se comparte

11 Ibidem. 457.

12 Ibidem. 458.

13 Ibidem. Pág. 461. 
el punto de partida, es decir, el recurso a una teoría absoluta. No obstante, cabría recordar que entre sus premisas está el "rechazo contundente" a las propuestas metodológicas que pretenden configurar el delito "a partir de y con referencia a la pena". En realidad, esto no es así, pues su concepción del delito responde a una teoría de la pena, la de la retribución. Por tanto, su objeción no es a que la teoría de la pena pueda configurar el delito, puesto que su tesis sobre este es fruto de su opción por la retribución. En realidad, su rechazo es a las teorías utilitarias. Pero si esto es así, no debería admitir que una pena justa y proporcionada a la gravedad del hecho quedara excluida por consideraciones utilitarias, de prevención. El excluirlas del delito y llevarlas al ámbito de la pena no resuelve el problema. Ciertamente cabría objetar que la autora no asume una teoría absoluta sino una unitaria. En efecto, dice la autora que "la adopción de una teoría unitaria de la pena no tiene que venir acompañada de una modificación de la estructura del delito, pues según la postura que aquí se defiende sólo la pena justa, proporcionada a la magnitud de lo injusto culpable -y no la pena funcional para el sistema- puede desplegar efectos de orden preventivo y, asimismo, satisfacer adecuadamente las exigencias de un Estado social y democrático de Derecho". Pero, como se puede ver, lo que se afirma es que solo la pena proporcionada a la gravedad del injusto culpable es la que puede desplegar efectos preventivos. Pero si esto es así, ¿Cómo se puede admitir que se pueda renunciar a esta por razones utilitarias? En su concepción lo coherente sería rechazar la legitimidad de tales circunstancias y no el excluirlas del delito para llevarlas al ámbito de unos presupuestos de la pena.

\section{La punibilidad como una categoría del delito}

Como he dicho, son cada vez más los autores que admiten la existencia de una categoría adicional a lo injusto culpable, para la que se utilizan diversas denominaciones (punibilidad, penalidad, otros presupuestos de la pena, etc.). 
Sin embargo, entre los partidarios de esta posición hay, al menos en apariencia, discrepancias tanto en lo relativo al fundamento de esta categoría como, sobre todo, en lo referente a su contenido.

\section{La fundamentación de la categoría}

Para un sector de la doctrina, el objeto de la punibilidad consiste en determinar si el recurso a la pena se puede justificar desde el punto de vista del Derecho penal en el contexto del sistema de control social. La función de proteger bienes jurídicos a través de la estabilización de las normas no es exclusiva de aquel, sino que incumbe a todas las instancias de control social. $\mathrm{Su}$ singularidad radica en que para satisfacer su función se sirve de las sanciones más graves de las que dispone el sistema de control social. Ello supone que el beneficio que trae consigo (la prevención) viene acompañado de los mayores costes (privación de bienes esenciales de la persona). De aquí que solo quepa recurrir a la pena cuando esto resulte funcional tanto para el sistema de control social como para el subsistema del Derecho penal. Este será el caso únicamente allí donde la función de la pena no se pueda alcanzar por otras vías menos costosas o no implique costes no sólo para el autor sino para terceros. En definitiva, la punibilidad obtiene su fundamento del principio de subsidiariedad que es una acuñación de los fines de la pena ${ }^{14}$.

14 Así, García Pérez, O.: La punibilidad en el Derecho penal. Aranzadi, Pamplona, 1997, págs. 380 y ss. En el mismo sentido, Maqueda Abreu, M. L. y Laurenzo Copello, P.: El Derecho penal en casos. Parte General. Teoría y Práctica. Tirant lo Blanch, Valencia, 2016, pág. 2019; Pérez Ferrer, F.: El desistimiento voluntario de la tentativa en el Código penal español. Dykinson, Madrid, 2008, págs. 135 y ss.; Lacruz López, J. M. en Gil Gil/Lacruz López/Melendo Pardos/Núñez Fernández: Sistema de responsabilidad penal. Dykinson, Madrid, 2017, pág. 99; Sánchez-Ostiz, P.: "Una aportación al estudio de la punibilidad. A propósito de la autodenuncia tras el fraude fiscal", en Urquizo Olaechea/Abanto Vásquez/Salazar Sánchez: Dogmática del Derecho penal económico y política criminal. Homenaje a Klaus Tiedemann. Vol. I. Universidad de San Martín Porres, Lima, 2011, págs. 681 y s.; Cocco, G.: La punibilità. Cuarto elemento del reato. Wolters KluwerCedam, Milán, 2017, págs. 101 y ss. 
Pozuelo Pérez considera que es imprescindible reconocer una categoría posterior al injusto y la culpabilidad, destinada a recoger las instituciones que conciernen "al si y al cómo de la pena". El principio rector de esta categoría lo sitúa la autora en la idea de la "utilidad de la pena, que está vinculada con la realización de intereses del ordenamiento que exceden de los que informan la sanción adecuada al injusto penal. En la medida en que se haya producido un injusto culpable eso significa que el contenido y fin de la pena relativa a aquél ya se habría afirmado. Pero...aún pueden existir razones de índole jurídica que afectan al hecho de que esa pena pueda verse todavía alterada, en todo o en parte ${ }^{15}$ ".

Ferré Olivé considera que "la punibilidad se refiere en exclusiva a la necesidad preventiva de la pena, en la que inciden conjuntamente elementos sustantivos y procesales. Estos elementos no se fundamentan en la afección culpable a un bien jurídico sino en razones políticas (de política jurídica y política criminal). Al constatar que una conducta reúne el conjunto de características exigidas (comportamiento humano típico, antijurídico y culpable), se afirma que es merecedora de pena, esto es, que sufre una desaprobación jurídica tan intensa que debería acarrear un castigo, o al menos permitir que dicho castigo sea posible. El delito ya ha alcanzado el grado de tentativa o consumación y por ello la pena es, desde una perspectiva valorativa, merecida. Sin embargo, ciertos supuestos muy concretos, fundamentados como hemos dicho en razones políticas, permiten al legislador establecer otro tamiz, añadiendo nuevos requisitos para que determinadas conductas efectivamente merecedoras de pena sólo se sancionen cuando dicha consecuencia jurídica sea necesaria. De tal forma, cuando un precepto penal incorpora una condición objetiva, una causa de exclusión de la punibilidad o es de aplicación un presupuesto procesal, se nos está indicando

15 Pozuelo Pérez, L.: El desistimiento en la tentativa y la conducta postdelitiva. Tirant, valencia, 2003, págs. 447 y ss. Subrayado en el texto original. 
que en estos casos, al apreciarse un elemento que excluye la punibilidad, una pena merecida no es necesaria" ${ }^{\prime 6}$.

Por su parte, Díez Ripollés entiende que la punibilidad se ocupa de "determinar si es necesario formular al sujeto un juicio de responsabilidad por el comportamiento realizado". La necesidad de efectuar dicho juicio se basa en razones de utilidad. De este modo, la punibilidad "se plantea si y en qué medida la formulación de un juicio de responsabilidad en el caso concreto sirve a los objetivos perseguidos con la intervención penal". La punibilidad viene a atender "a si el juicio de responsabilidad cumple fines insertos en otros lugares del sistema de exigencia de responsabilidad, o incluso fuera de él". A su entender, son tres los juicios de utilidad que configuran esta categoría. El primero es el de la efectividad. Esta aludiría a la cuestión de si la formulación del juicio de responsabilidad "sirve al objetivo de cumplimiento de la norma correspondiente o de su aplicación coactiva en caso necesario". Aquí incluiría el autor los supuestos de colaboración con la acción de la Administración de Justicia como, por ejemplo, la atenuante de confesión del hecho. El segundo sería el de la eficacia. Aquí se trataría de evaluar si el juicio de responsabilidad "contribuye a la obtención de los objetivos perseguidos con la intervención penal, en especial la tutela de ciertos bienes o intereses, pero también los límites asignados a la responsabilidad penal y a las reacciones penales". En este grupo coloca el autor las conductas de reparación del daño que hay tanto en la Parte General como en la Especial del Código penal. El tercero sería el de la eficiencia donde hay que analizar si "los intereses satisfechos por ese juicio de responsabilidad están por encima de los intereses que la formulación de ese juicio deja de lado"17.

16 Ferré Olivé, J. C.: "Punibilidad y proceso penal", en Revista General de Derecho penal, 10, 2008, págs. 7 y s. Por su parte, Cuello Contreras/Mapelli Caffarena: Curso de Derecho penal. Parte General. Reimpresión de la $3^{\text {a }}$ ed. Tecnos, Madrid, 2016, pág. 147, entienden que los aspectos de la punibilidad se basan "en razones de conveniencia y oportunidad" (el subrayado corresponde al original).

17 Díez Ripollés, J. L.: "La categoría de la punibilidad en el Derecho penal español”, en Estudios de Derecho penal. Homenaje al profesor Santiago 
Con esta terminología el autor alude a una serie de grupos de supuestos que la doctrina ya ha identificado. Así, por ejemplo, con la referencia a la eficiencia alude a un grupo de casos que un importante sector de la doctrina identificaba como aquellos basados en razones de política jurídica o en criterios ajenos al Derecho penal ${ }^{18} \mathrm{o}$ intereses no directamente vinculados con la sanción penal ${ }^{19}$ y que tradicionalmente han representado un quebradero de cabeza para quienes defendían que no había espacio más allá de lo injusto culpable para la ubicación de otra categoría. Y lo mismo sucede con los supuestos que ubica en la efectividad y eficacia. Representan circunstancias que ya han sido reconocidas por la doctrina si bien no es habitual diferenciarlas dado que ambas afectarían a la función de prevención perseguida con el recurso a las sanciones penales ${ }^{20}$.

Otro problema que plantea el uso de esta terminología es que, hasta donde alcanzo a ver, no son tres conceptos que se puedan emplear en un mismo ámbito, sino que estamos hablando de diversos criterios para medir el grado de funcionamiento óptimo en un determinado sector (administrativo, económico, sanitario, etc.). Se puede decidir que lo único que importa es la consecución de los objetivos, que lo relevante es el menor uso posible de los recursos aunque a veces ello pueda impedir la satisfacción de las metas, o que lo decisivo es la consecución de los objetivos con el menor uso posible de recursos, es decir,

Mir Puig. IBdeF, Montevideo-Buenos Aires, 2017, págs. 527 y s. Asumen esta posición Melendo Pardos, M. en Gil Gil/Lacruz López/Núñez Fernández: Sistema de Responsabilidad penal. Op. Cit., págs. 474 y s.; Núñez J.: "Algunas reflexiones sobre la punibilidad en el tratamiento jurídico penal del terrorismo", en Gil Gil/Maculan: La influencia de las victimas en el tratamiento jurídico de la violencia colectiva. Dykinson, Madrid, 2017, págs. 267 y s.

18 Así, por ejemplo, Roxin, C.: Strafrecht. A. T. $3^{\text {a }}$ ed. C. H. Beck, Munich, 1994, pág. 872; Bloy, R.: Die dogmatische Bedeutung der Strafausschließungs- und Strafaufhebungsgründe. Duncker \& Humblot, Berlín, 1976, págs. 224 y ss.

19 García Pérez, O.: La punibilidad. Op. Cit., págs. 342 y s.

20 Ibidem. Pág. 343. 
es preciso buscar el equilibrio entre los dos primeros criterios. Por lo demás, también hay que destacar el uso tan dispar que se hace de estos conceptos. De hecho, por ejemplo, el Diccionario jurídico español define la eficiencia como "principio a que está sometida la Administración Pública conforme al cual debe procurar alcanzar los objetivos de interés público mediante el uso del mínimo de medios necesarios" ${ }^{21}$. Por ello entiendo que la Administración Pública, en este caso la justicia penal, no puede decidir libremente ser eficaz en ocasiones, otras eficiente y otras efectiva, sino que debería optar por una de ellas que es lo que plantea el principio de eficiencia tal como lo define el Diccionario del español jurídico. Por tanto, se trataría de alcanzar los objetivos con el menor consumo posible de recursos que es lo que en el ámbito del Derecho penal viene a plantear el principio de subsidiariedad.

En su magnífica monografía Costa Pinto señala que la punibilidad viene a añadir tres juicios de valor sobre elementos materiales ${ }^{22}$. Estos juicios de valor son la idoneidad, la necesidad y la proporcionalidad en relación a la amenaza de la pena estatal y los elementos materiales son circunstancias extrañas al hecho ilícito, pero relacionadas con el mismo ${ }^{23}$. Estas circuns-

21 Definición consultada en https://dej.rae.es/lema/eficiencia

22 Téngase presente que este autor entiende que una categoría dogmática es la síntesis de los aspectos materiales del hecho con los juicios de valor. Cfr. Costa Pinto, F. da: A categoria da punibilidade na teoria do crime. 2 vols., ed. Almedina, Coimbra, 2013, pág. 886.

23 En nuestra doctrina, vinculan la punibilidad al principio de proporcionalidad si bien ellos ubican esta categoría fuera del delito, Orts Berenguer/González Cussac: Compendio de Derecho Penal. Parte General. $4^{\mathrm{a}}$ ed. Tirant lo Blanch, Valencia, 2014, págs. 325 y ss. Estos autores señalan que la proporcionalidad desempeña una doble función en la teoría jurídica del delito: primero juega un papel esencial para fijar la necesidad de pena en abstracto en el seno de cada una de las pretensiones de contenido material (relevancia, ilicitud y reproche); y, segundo, posteriormente configura una categoría autónoma o pretensión de validez de la norma, en la que se trata de examinar si en el caso concreto la pena que corresponde imponer supera también el «juicio de proporcionalidad», y resulta ser idónea, necesaria y proporcional". Más adelante añaden que "la pretensión de necesidad de pena viene 
tancias serían al menos las condiciones objetivas de punibilidad, las causas de exclusión y las de anulación de la pena. La evaluación realizada mediante la articulación entre juicios de valor y los mencionados elementos materiales puede incidir sobre la idoneidad de los medios para perseguir los fines, sobre el fin perseguido en sí mismo o sobre la relación entre los medios y los fines o sobre las consecuencias provocadas por aquel medio para alcanzar un determinado fin. Por tanto, para este autor el fundamento de esta categoría reside en el principio de proporcionalidad en sentido amplio.

Conforme a la tesis de este autor faltará la idoneidad cuando la respuesta penal no es adecuada por buscar un fin inalcanzable. También faltará este requisito cuando la intervención penal en nada puede contribuir a lograr el fin que pretende o cuando el objetivo buscado se ha conseguido por otra vía. Otro supuesto de inidoneidad se da cuando la respuesta penal trae consigo resultados ajenos a sus fines, especialmente cuando provoca consecuencias negativas para los derechos fundamentales o el sistema penal sin conseguir promover los fines que la legitiman. Finalmente tampoco se dará la idoneidad cuando la contribución de la intervención penal para alcanzar el fin perseguido acaba por dificultar la posibilidad de lograrlo ${ }^{24}$.

a coincidir con una «nueva» categoría que recibe diversos nombres, como punibilidad, penalidad, o merecimiento y necesidad de pena". Tras señalar que se discute casi todo lo relacionado con ella, indican que "se trata de una temática de creciente interés y, en términos generales, vinculada a la idea de utilidad". Para ellos, "únicamente es legítima la pena, en abstracto y en concreto, para castigar hechos que lesionan o ponen en peligro bienes jurídicos valiosos, cuando, por la forma y gravedad del ataque sufrido por éstos, el resto del ordenamiento jurídico resulta insuficiente, y en la medida en que el castigo sea socialmente útil y equilibrado respecto de la trascendencia del hecho". Más adelante, cuando estudian los diversos grupos de circunstancias que se incluirían en esta categoría, dejan claro que sus circunstancias no afectan a la existencia del delito (págs. 397 y 409). La cursiva corresponde a los autores.

24 Costa Pinto, F. da: A Categoría. Op. Cit., págs. 1010 y ss. 
La necesidad se traduce, según este autor, en que la actuación del Derecho penal, además de idónea, debe aparecer como el medio menos lesivo de cuantos dispone el legislador o el operador jurídico para alcanzar los fines propuestos. Así faltará este requisito cuando la intervención penal no constituye la ultima ratio del sistema público de sanciones. Entiende que se lesionaría la necesidad si se castigasen todas las riñas con independencia de sus consecuencias o de su peligrosidad o si no se exigiese que el suicidio al menos se haya intentado en el caso de la inducción o auxilio al suicidio. Finalmente señala que faltará la necesidad cuando ya se logró por otra vía el fin perseguido por el legislador, lo que acontece en el caso del desistimiento de la tentativa, reparación del daño, etc.

En cuanto a la proporcionalidad en sentido estricto, indica que entraña una ponderación entre la gravedad del delito y la de la pena. Pero añade que en el plano de la legitimidad material de la respuesta penal la ponderación se debe extender a las consecuencias de la conminación penal que se suman a la gravedad abstracta de la pena. De este modo, los daños ocasionados por la sanción penal no pueden ser manifiestamente superiores a las ventajas que la misma consigue alcanzar, pues ello implicaría que la amenaza de la pena es desproporcionada en sí misma. Añade que la pena inidónea puede ser desproporcionada y que la innecesaria siempre lo es. Considera que la pena es desproporcionada cuando para alcanzar los objetivos pretendidos pone en peligro la tutela del bien jurídico o puede provocar un daño superior al causado por la imprudencia del sujeto. Un ejemplo de ello sería el castigo de la insolvencia sin exigir una previa sentencia judicial que la declare. No hay proporcionalidad cuando la pena lesiona intereses superiores a los que tutela y que solo pueden ser garantizados con la renuncia a la misma. Este sería el caso de las inmunidades. Por último, la pena es desproporcionada en los supuestos de escasa gravedad del hecho, lo que acontece en la criminalidad de bagatela. En las hipótesis en las que el tipo penal no sea susceptible de una interpretación restrictiva, la punibilidad gozará de autonomía para retirar del ámbito de la 
incriminación un hecho típico que no debe ser punible por razón de la proporcionalidad que debe presidir la intervención penal ${ }^{25}$.

A mi juicio, es bastante convincente la fundamentación de la punibilidad en la idoneidad y la necesidad, pero no así en la proporcionalidad en sentido estricto. Hasta donde alcanzo a ver la mayor parte del contenido que atribuye a la proporcionalidad en sentido estricto se refiere a casos de falta de idoneidad o necesidad. El único supuesto que creo que sí que entra de lleno en la proporcionalidad es el de la criminalidad de bagatela. Aquí señala que si no es posible la interpretación restrictiva de un tipo penal para excluir los hechos insignificantes, estos podrían dejarse impunes a través de la punibilidad. En mi opinión, si no fuera posible esa interpretación restrictiva, lo que sucedería es que estaríamos ante un precepto inconstitucional por violación de la proporcionalidad sin que en este caso sea la punibilidad la llamada a resolver este caso. Por otro lado, la proporcionalidad en sentido estricto no puede ponderar idoneidad y necesidad de la pena, y la gravedad del hecho, puesto que son magnitudes que van en direcciones distintas. Puede haber una elevada necesidad de prevenir unos hechos y, por tanto, de incrementar la pena, siendo así que los mismos ya tienen una sanción acorde con la gravedad de los hechos. El problema que plantea la proporcionalidad en sentido estricto es cuál debe ser su punto de referencia. A mi entender, como he tratado de argumentar en otro lado ${ }^{26}$, si no queremos sacrificar a las personas más allá de lo que se deriva de su conducta, la proporcionalidad debe relacionar la importancia del bien jurídico y la entidad del ataque al mismo, es decir, la gravedad de lo injusto, con la gravedad de la pena, de tal modo que por muchas que sean las necesidades preventivas, la proporcionalidad impediría incrementar las sanciones en función de estas. Por tanto, la proporcionalidad vendría a fijar el lí-

25 Ibidem. Pág. 1015.

26 García Pérez, O.: "La racionalidad de la proporcionalidad en sistemas orientados a la prevención especial", en Revista electrónica de ciencia penal y criminología, $\mathrm{n}^{\circ} 9,2007$, págs. 1 y ss. 
mite máximo de la intervención penal, pero no así el mínimo que este sí que depende de las necesidades preventivas que pueden ser inferiores o incluso nulas, lo que justificaría una reducción o incluso una renuncia a la pena ${ }^{27}$.

A la vista de todo lo expuesto en este apartado, creo que hay un amplio acuerdo en considerar que es la utilidad ${ }^{28}$ la que da sentido a la punibilidad. En este sentido me parece que no se dice nada distinto cuando se habla de juicios de eficiencia, de racionalidad conforme a fines, de racionalidad pragmática o de idoneidad y necesidad. Llegados a este punto, la cuestión que, a mi juicio, habría que plantear es la relativa a dónde buscar en el Derecho penal esos criterios de utilidad y en qué consisten. Y entre todos los principios que orientan el Derecho penal es el de subsidiariedad el que claramente los usa. Es lugar común entre buena parte de los partidarios de admitir la punibilidad que dentro de la misma deben encuadrarse las circunstancias que eximen de pena porque su objetivo ya se ha conseguido por otras vías. Por eso me parece que aludir a la subsidiariedad supone un paso más en la determinación de cómo son y cómo funcionan esos juicios de utilidad. Frente a otras terminologías, el recurso a la subsidiariedad tiene la ventaja de constituir un principio ampliamente asentado en el Derecho penal frente a terminologías,

27 Destacando la diversidad de perspectivas en las que se basan idoneidad, necesidad y proporcionalidad estricta, señala Arroyo Zapatero, L.: "Derecho penal económico y Constitución”, en Revista Penal, $n^{\circ} 1$, pág. 11, que "mientras que la idoneidad y necesidad tienden a enjuiciar la sanción desde un punto de vista eminentemente utilitarista - adecuación y economía de los medios - la idea de proporcionalidad en sentido estricto se fundamenta directamente en la idea de justicia, desde la cual se debe ponderar si el beneficio que se pretende alcanzar con la sanción justifica sus costes. Esta manifestación del principio de proporcionalidad es la que se invoca cuando se habla del carácter fragmentario del derecho penal o del merecimiento de pena de un comportamiento".

28 Se trata, como hemos visto, de una idea incluso compartida por quienes no admiten la punibilidad como categoría del delito. Marinucci/Dolcini/Gatta: Manuale de Diritto Penale. Parte Generale. $7^{\mathrm{a}}$ ed. Giuffrè, Milán, 2018, págs. 439 y s., consideran que los elementos de esta categoría son circunstancias que fundamentan o excluyen la oportunidad de penar al sujeto. 
a mi juicio, más imprecisas como las referencias a la necesidad de la pena y otras semejantes.

\section{El alcance de la punibilidad}

En cambio, en relación al alcance de la punibilidad, todavía es difícil vislumbrar un acuerdo. En efecto, los contenidos de esta categoría son sumamente discutidos. En principio hay consenso en que en este elemento del delito habría que incluir las condiciones objetivas de punibilidad y una parte de las excusas absolutorias: las concurrentes al tiempo de la comisión del hecho que, siguiendo la terminología alemana, un sector de la doctrina prefiere denominar causas de exclusión de la pena.

En efecto, un sector de la doctrina entiende que no pueden formar parte de la punibilidad aquellas circunstancias que aparecen después de la infracción de la norma. Este es el caso de los comportamientos postdelictivos. Así, Faraldo Cabana señala en relación a estos que "las causas de levantamiento o anulación de la pena consisten en un comportamiento positivo del sujeto, realizado después de la ejecución del hecho delictivo. Al ser posteriores a la ejecución del hecho no afectan a los elementos del delito: situadas fuera de la antijuridicidad, la culpabilidad y la punibilidad, constituyen un presupuesto de la pena distinto del delito"29. Se trata de una idea que ya había sostenido De Vicente Remesal al definir el comportamiento postdelictivo como aquel que es posterior a la consumación formal, lo que, a su juicio, impediría incluirlo en la teoría jurídica del delito, pues en ella no caben las conductas realizadas tras la infracción de la norma. Este autor señalaba que las teorías absolutas no permitían dar cabida a este tipo de circunstancias, lo que, en cambio, no planteaba problemas en las teorías relativas, pues en estas la valoración se extendía hasta la celebración del proceso. Pese a ello, este autor no reconoció que este momento tuviera carácter

29 Faraldo Cabana, P.: Las causas de levantamiento de la pena. Tirant lo Blanch, Valencia, 2000, págs. 99 y 177 y s. En este sentido también, Martínez-Buján Pérez, C.: Derecho penal económico y de la empresa. Parte General. $5^{\text {a }}$ ed., Tirant lo Blanch, Valencia, 2017, págs. 651 y ss. 
constitutivo para la teoría jurídica del delito. A su juicio, el proceso solo reviste este carácter para la determinación de la pena ${ }^{30}$.

Otros autores incluyen también en la punibilidad las excusas absolutorias basadas en comportamientos posteriores a la consumación de la infracción penal. Se trata de una posición bastante extendida ${ }^{31}$.

Por último, un sector de la doctrina incluye otros elementos en la punibilidad. Ciertamente tampoco hay consenso en torno a todos los demás aspectos que habría que incorporar a esta categoría. Para algunos también pertenecerían a esta las causas de extinción de la responsabilidad criminal ${ }^{32}$. Así, por ejemplo, Muñoz Conde opta por recoger estas circunstancias en el tema de la penalidad, resaltando que son "de difícil encuadre sistemático en la Teoría General del Delito, pero que por su carácter excluyente de la imposición o ejecución de la pena, pueden

30 Vicente Remesal, J. de: El comportamiento postdelictivo. Universidad de León, 1985, págs. 42, 359 y ss. En este sentido también, Luzón Peña, D. M.: Voz "Punibilidad", en Enciclopedia jurídica básica. Vol. IV. Civitas, Madrid, 1995, págs. 5424 y 5428; el mismo: Lecciones de Derecho penal. Parte General. $3^{\mathrm{a}}$ ed. Tirant lo Blanch, Valencia, 2016, págs. 554 y s.

31 En este sentido, por ejemplo, Díez Ripollés, J. L.: Derecho penal español. Parte General. Tirant lo Blanch, Valencia, 2016, págs. 543 y ss.; Maqueda Abreu/Laurenzo Copello: El Derecho penal. Op. Cit., págs. 220 y s.; Con numerosas referencias a la doctrina alemana y portuguesa, Costa Pinto, F. da: A categoría. Op. Cit., pág. 1072 nota 333. Para este autor "la reconducción de las causas de levantamiento de la pena a la teoría de las consecuencias jurídicas del delito (con la consiguiente desvinculación de estas figuras del hecho y de los presupuestos materiales del delito) no puede ser aceptada solamente en función de la identificación de la figura en sí misma: o bien existe una conexión inmediata de esta circunstancia con el hecho y, en tal caso, estamos frente a parcelas del complejo fáctico y no frente a simples presupuestos de la pena; o, por el contrario, no existe tal conexión y, por ello, no estamos frente a elementos materiales que puedan integrarse en el concepto jurídico de delito. En cualquier caso, debería ser el criterio de delimitación material del suceso fáctico penalmente relevante el que determine la solución sistemática y no la pura cualificación dogmática de la figura o una arbitraria organización de los elementos en cuestión” (pág. 1073).

32 Así, por ejemplo, Marinucci/Dolcini/Gatta: Manuale. Op. Cit., págs. 439 y ss.; Muñoz Conde/García Arán: Derecho penal. Parte General. 9a ed., Tirant lo Blanch, Valencia, 2015, págs. 427 y ss. 
estudiarse también aquí" ${ }^{\prime 3}$. Marinucci, Dolcini y Gatta señalan que "junto a las causas personales y objetivas de no punibilidad, el ordenamiento ha previsto ulteriores causas de exclusión de la punibilidad denominadas «causas de extinción del delito», una fórmula que subraya como con la extinción del delito viene a cesar la posibilidad de realizar la pretensión punitiva del Estado. Se trata de institutos que cobran vida de forma completamente independiente de los comportamientos del autor o que no se agotan en la conducta del mismo...y que, apareciendo después de la comisión del hecho ilícito y culpable y antes de la condena definitiva, implican la inaplicabilidad de cualquier sanción penal prevista para aquel delito específico"34.

Tampoco faltan las opiniones que incorporan a la punibilidad las condiciones de procedibilidad ${ }^{35}$. En este sentido, Ferré Olivé indica que "no puede desconocerse que algunas instituciones procesales también se encuentran guiadas por criterios de necesidad de pena, y pueden ubicarse perfectamente dentro de la punibilidad. Por una parte, es necesario contar con el elemento punibilidad como colofón de una exposición sistematizada del delito. Por otra, es difícil encontrar criterios distintivos que sean concluyentes entre las tradicionales causas de exclusión de la punibilidad y los presupuestos procesales. Todos tienen en común que son elementos ajenos al delito y que imposibilitan la imposición de la pena. Es decir, como en su día enfatizó Franz von Liszt, deben ser oportunamente analizados pero separadamente del delito. Debemos también recordar que desde una perspectiva histórica, la asignación de los presupuestos procesales al ámbito penal o procesal ha estado condicionada por circunstancias

33 Muñoz Conde/García Arán: Derecho penal. PG. Op. Cit., pág. 428.

34 Marinucci/Dolcini/Gatta: Manuale. Op. Cit., pág. 452.

35 En este sentido, Cuello Contreras/Mapelli Caffarena: Curso. Op. Cit., pág. 147 y ss.; Ferré Olivé, J. C.: Punibilidad. Op. Cit., págs. 10 y ss. Asúa Batarrita, A.: "Causas de exclusión o de restricción de la punibilidad de fundamento jurídico constitucional", en El nuevo Código Penal: presupuestos y fundamentos: (libro homenaje al profesor Doctor Don Angel Torí López). Comares, Granada, 1999, págs. 221 y ss., quien incluye una serie de circunstancias relativas a problemas que se suscitan en el proceso penal. 
coyunturales, es decir, por las necesidades y urgencias políticas de cada época. El legislador ha hecho uso de estas categorías de forma intercambiable (como ya hemos recordado, algunos presupuestos procesales se encuentran previstos en el texto del propio Código Penal). La asignación al Derecho penal o al Derecho procesal sigue estando hoy en manos del libre criterio legislativo o de valoraciones interpretativas. Considerando que un análisis que busque con seriedad sus fundamentos materiales debe conducir a integrar estos elementos en la punibilidad"36.

\section{Pautas superar algunas objeciones}

\section{Introducción}

Como he indicado antes, creo que en el ámbito del fundamento no es difícil lograr un consenso, pues hay un amplio acuerdo en considerar que es la utilidad la que da sentido a la punibilidad y probablemente cabría acordar que en el Derecho penal esa utilidad se concreta en el principio de subsidiariedad.

En mi opinión, son dos las cuestiones que en gran medida están impidiendo lograr un consenso en torno al reconocimiento de la categoría de la punibilidad. La primera se refiere al papel de la teoría de la pena en la configuración del delito. La segunda alude al momento constitutivo del delito. A continuación, me ocuparé de cada uno de estos temas.

\section{La interrelación entre delito y teoría de la pena}

Como acabo de indicar, la primera de ellas es la afirmación que con frecuencia se realiza en la doctrina, incluso entre la favorable a la admisión de esta categoría, y que vendría a decir que el delito no se puede configurar "a partir de y con referencia a la pena" ${ }^{" 37}$ o no se puede vincular a la teoría de la pena ${ }^{38}$.

36 Ferré Olivé, J. C.: Punibilidad. Op. Cit., pág. 10.

37 Así, por ejemplo, Mendes Carvalho, E.: Punibilidad. Op. Cit., pág. 467.

38 Así, por ejemplo, Díez Ripollés, J. L.: Derecho penal. Op. Cit., págs. 541 y ss. 
El delito y las consecuencias jurídicas previstas para este constituyen la base del Derecho penal. Así lo acreditan las definiciones que de este se formulan. En efecto, si nos preguntamos por el concepto de Derecho penal, cabría en principio ensayar definiciones como las siguientes:

"Derecho penal es el conjunto de las reglas jurídicas establecidas por el Estado, que asocian el crimen, como hecho, a la pena, como legítima consecuencia" 39 .

Derecho penal es "un conjunto de normas jurídicas que asocian a la realización de un delito como presupuesto, la aplicación de penas y/o medidas de seguridad, como principales consecuencias jurídicas" ${ }^{40}$.

"El Derecho penal es el conjunto de todos los preceptos que regulan los presupuestos o consecuencias de una conducta amenazada con una pena o una medida de corrección y de seguridad"41.

A partir de este último concepto, dice Roxin que "pena y medida son el punto de referencia común de todos los preceptos penales. Esto significa que el Derecho penal en sentido formal se define a través de sus sanciones. Un precepto no pertenece al Derecho penal sólo porque estipule la infracción de mandatos o prohibiciones -eso lo hacen también muchos preceptos civiles y administrativos-, sino porque esta infracción se sanciona con penas o medidas" ${ }^{42}$.

Pero ciertamente no nos podemos conformar con un concepto meramente formal de Derecho penal, sino que es preciso dotarlo de contenido material. En las definiciones que hemos visto, el Derecho penal posee dos componentes: delitos y con-

39 Así definía hace un siglo von Liszt el Derecho penal (Tratado de Derecho penal. Trad. de L. Jiménez de Asúa y anotaciones de Quintiliano Saldaña. Reus, Madrid, sin fecha, pág. 5).

40 Así, Muñoz Conde, f. en Muñoz Conde/García Arán: Derecho penal. $O p$. Cit., págs. 22 y s.

41 Roxin, C.: Strafrecht. Op. Cit., pág. .

42 Ibidem (subrayado añadido). 
secuencias jurídicas. Pues bien, ya Gallas planteaba la cuestión de si no sería posible determinar el contenido de alguno de los componentes a partir del otro. A primera vista ello no es posible, pues si se define el delito como un hecho sancionado con pena nos seguimos situando en el plano formal, y lo mismo sucede con la pena, puesto que esta solo se puede conceptuar por referencia al delito. Para salir de este círculo vicioso, proponía acudir a "la esencia y la función" de la pena, pues si se dilucida cuál es el fin que la sociedad persigue cuando amenaza con pena únicamente determinados hechos, a partir de ahí será posible fijar las características que tienen que reunir los delitos ${ }^{43}$. Así, la pena también cobra una importancia trascendental de cara a la configuración material del Derecho penal desde la perspectiva de un método teleológico ${ }^{44}$. No se trata de introducir la pena o sus fines en los presupuestos de la intervención, es decir, en el delito, sino de averiguar cuáles podrían ser estos teniendo presente la esencia y/o los fines de la pena. O dicho de otro modo, se buscaría determinar qué características deberían revestir los comportamientos que van a ser objeto de intervención a la vista de aquello que diferencia al Derecho penal de otros sectores del ordenamiento: la gravedad de sus consecuencias jurídicas y/o los fines que persiguen. Por tanto, lo que se pretende es descubrir qué aspectos del hecho o vinculados con él deberían integrarse en el delito.

Implícita o explícitamente este proceder se utiliza continuamente. Así acaece cuando se erigen en principios básicos los de exclusiva protección de bienes jurídicos y de fragmentariedad. ¿Por qué solo pueden constituir delito los comportamientos que afecten a bienes jurídicos? ¿Por qué el Derecho penal únicamente debe considerar delito los ataques más importantes a los bienes jurídicos más relevantes? La respuesta a estas cuestiones

43 Gallas, W.: Beiträge zum Verbrechenslehre. Walter de Gruyter, Berlin, 1968, págs. 1 y ss.

44 Como el propio destaca, Roxin, C.: Politica criminal y sistema del Derecho penal. Trad. de F. Muñoz Conde. Bosch, Barcelona, 1972, especialmente págs. $67 \mathrm{y}$ ss. 
es siempre la misma. En efecto, al ser la pena -como ya decía von Liszt- un medio de "protección de bienes jurídicos a través de la lesión de bienes jurídicos" 45 y no de cualesquiera, sino de los más esenciales de la persona, sólo se debe recurrir a ella en los casos de ataques intensos a los bienes más importantes ${ }^{46}$. Estos principios han cumplido y cumplen un papel muy destacado en la configuración de lo injusto, descartando aquellas configuraciones de los tipos que lleven a prescindir del bien jurídico o recortando el alcance de los mismos para excluir hechos de escasa entidad. O piénsese en las reflexiones que se han hecho en el sentido de afirmar que una pena solo puede ser justa si responde a las exigencias del principio de culpabilidad ${ }^{47}$ y las enormes repercusiones que este ha tenido tanto en la imputación subjetiva como en la configuración de la categoría de la culpa-

45 Liszt, F. von: Strafrechtliche Vorträge und Aufsätze. T. I. Reimpresión de la edición de 1905, Walter de Gruyter, Berlin, 1970, pág. 161. En términos similares se manifiestan también Roxin, C.: Problemas básicos del Derecho penal. Trad. de D. M. Luzón Peña. Reus, Madrid, 1976, págs. 21 y ss., y Muñoz Conde, F.: Introducción. Op. Cit. pág. 71.

46 Así, por ejemplo, Muñoz Conde, F.: Introducción al Derecho penal. Bosch, Barcelona, 1975, págs. 59 y 71 y ss.; Díez Ripollés, J. L.: El Derecho penal. Op. Cit. págs. 83 y ss.; Portilla Contreras, G.: "El principio de intervención mínima y bienes jurídicos colectivos", en $C P C \mathrm{n}^{\circ} 39$, 1989, pág. 740; Cuerda Arnau, M. L.: "Aproximación al principio de proporcionalidad en Derecho penal", en Estudios jurídicos en memoria del profesor Dr. D. José Ramón Casabó Ruiz. T. I. Valencia, 1997.págs. 470 y s.; Günther, H. L.: Strafrechtswidrigkeit und Strafunrechtsausschluß. Carl Heymann, KölnBerlin-Bonn-München, 1983, pág. 238. En verdad, los principios de insignificancia (Roxin, C.: Política. Op. Cit., pág. 53) o el de minima non curat praetor (Liszt, F. von: Tratado de Derecho penal. T. II. Trad. de L. Jiménez de Asúa y anotaciones de Quintiliano Saldaña. Reus, Madrid, sin fecha, pág. 21) no son más que formulaciones negativas del de fragmentariedad. Cfr. respecto a la conexión del primero de ellos con este último, Luzón Peña, D. M.: "Causas de atipicidad y causas de justificación", en Causas de Justificación y de atipicidad en Derecho penal. Aranzadi, Pamplona, 1995, págs. 28 y ss.

47 Así, por ejemplo, Engisch, Karl: Auf der Suche nach der Gerechtigkeit. Piper, Munich, 1971, págs. 174 y s.; Müller-Dietz, H.: "Integrationsprävention und Strafrecht: zum positiven Aspekt der Generalprävention", en Festschrift für Hans-Heinrich Jescheck zum 70. Geburtstag. T. II. Duncker \& Humblot, Berlin 1985, pág. 823. 
bilidad. Tradicionalmente se ha prestado atención a los aspectos relacionados con la pena, sin que los relacionados con los fines de esta hayan estado a la misma altura debido al papel que las concepciones absolutas jugaron en la configuración de la teoría del delito. En efecto, en el momento de construcción de esta, los defensores de la prevención especial limitaron sus consideraciones a la política criminal, asumiendo el esquema del delito elaborado desde las teorías absolutas ${ }^{48}$.

El método teleológico supone que siempre hay que tener presentes las consecuencias jurídicas cuando se aborda el otro elemento del Derecho penal: el delito ${ }^{49}$, y, en definitiva, cuando se trata de dotar de contenido material a este sector del ordenamiento jurídico.

Problema distinto es que esta metodología puede tener un alcance muy diverso. Ello depende de que la orientación se refiera a la esencia de la pena y a los fines de la pena ${ }^{50} \mathrm{o}$ sólo a estos últimos y cuáles sean los que cada uno asigna a la sanción penal ${ }^{51}$. La opción por una vía u otra tiene importantes repercusiones. En efecto, la pena por su esencia representa una privación o restricción de bienes esenciales de la persona. Desde este punto de vista, la sanción aparece contemplada desde la perspectiva del individuo y representa un mal gravísimo que requiere una

48 Cfr. García Pérez, O.: La punibilidad. Op. Cit., págs. 355 y ss.

49 En este sentido, Schmidhäuser, E.: Strafrecht. AT. J. C. B. Mohr, Tübingen, 1970, pág. 110, señala que el método teleológico "significa que siempre hay que preguntarse por la consecuencia jurídica de la pena cuando se abordan los elementos del delito y su ordenación". Aclara este autor que el término teleológico se utiliza en cuestiones de interpretación en el sentido de que "hay que interpretar en atención al fin", pero desde un punto de vista metodológico supone que "no sólo la interpretación del precepto penal singular sino ya la propia comprensión del delito como tal, de sus elementos generales y de su ordenación, está orientada teleológicamente".

50 Así, por ejemplo, Gallas, W.: Beiträge. Op. Cit. págs. 3 y ss.

51 En este sentido se había manifestado ya Radbruch, G.: "Zur Systematik der Verbrechenslehre", en Festgabe für Reinhard Frank. T. I. J. C. B. Mohr, Tübingen, 1930, pág. pág. 163. Esta es también la opción de Jakobs, G.: Strafrecht. AT. $2^{\text {a }}$ ed. Walter de Gruyter, Berlin-New York, 1991, passim. 
especial legitimación. En cambio, si se la contempla desde el punto de vista de su fin, la pena aparece como algo socialmente útil. En esta otra vertiente la consecuencia jurídica se contempla desde el punto de vista de la sociedad ${ }^{52}$. Por tanto, la configuración difiere notablemente según se atienda solo a los fines de la pena o se incluya también la esencia de la pena, o incluso solo se atienda a esta última que ha sido la posición que han adoptado las teorías absolutas. En cualquier caso, lo que el enfoque teleológico ha venido a destacar, como indica Schmidhäuser, es que ha de existir una estrecha conexión entre aquello que es presupuesto para la consecuencia jurídica y esta ${ }^{53}$. Esto implica que en el presupuesto de la intervención, el delito, se deben recoger el hecho, sus efectos y todas las demás circunstancias que lo rodean que tengan relevancia para la función asignada a la pena. Así lo hace, como hemos visto, Mendes de Carvalho, cuando

52 Nótese la diferencia en el punto de partida con un enfoque orientado sólo a los fines de la pena como el de Jakobs, G.: Strafrecht. Op. Cit. pág. 6, cuando señala que su concepción se distingue de una imagen de la pena bastante extendida: "lo injusto es un mal y el deber del autor de soportar los costes es también un mal, pero pese a ello no se puede definir la pena como imposición de un mal a causa del mal cometido. Sería absurdo «querer un mal porque ya existe otro mal» y esta secuencia del mal define la pena únicamente a través de una "característica superficial». La pena tiene que ser definida positivamente: es demostración de la validez de la norma a costa de uno competente. De ahí surge un mal, pero la pena no ha cumplido con este efecto su función, sino sólo con la estabilización de la norma lesionada". Aquí la esfera individual ocupa un plano bastante secundario en relación a la esfera social.

53 Schmidhäuser, E.: "Über einige Begriffe der teleologischen Straftatlehre", en $J u S, 1987$, pág. 374. En este sentido, Frisch, W.: "Pena, delito y sistema del delito en transformación”, en Indret, 3/2014 (trad. de Ivó Coca Vila), pág. 21, señala que "la teoría de la pena y el concepto de delito constituyen una unidad: el concepto de delito y sus presupuestos conceptuales deben estar configurados de un modo tal que aquellos legitimen la imposición de la pena. Esto únicamente es posible cuando tales presupuestos conceptuales del delito están configurados en atención al concepto de pena, esto es, cuando el principio rector de la imposición de la pena está también detrás del diseño de los presupuestos del delito. Por el contrario, no es adecuado extraer los requisitos del hecho punible de una fuente distinta al principio del que se sigue la imposición de la pena". 
en su crítica a García Pérez señala que "la idea de insertar en la estructura delictiva una categoría basada exclusivamente en la utilidad social de la pena ... contradice el principio material de justicia, de validez a priori, del respeto a la dignidad de la persona humana. Una categoría así configurada no puede, por tanto, funcionar como un criterio seguro para ofrecer el fundamento y el límite de la pena. Por todo lo dicho anteriormente, sólo la idea de pena justa y proporcionada a la gravedad de lo injusto y la culpabilidad, es decir, la idea de retribución, puede operar como un límite del ius puniendi estatal" ${ }^{\prime 4}$. De este modo, la decisión de esta autora es coherente con su punto de partida, la retribución, pero con ello pone de relieve, como hemos visto, que la configuración del delito está estrechamente vinculada con la teoría de la pena elegida. Algo parecido se puede sostener respecto de la concepción de Díez Ripollés, pues aunque señale que los aspectos de la teoría de la pena no se pueden incluir en la punibilidad, lo cierto es que los principios que, según él, la fundamentan (eficacia, efectividad y eficiencia), corresponden a una lógica utilitaria y esta siempre pondera medios y fines. Una vez infringida la norma primaria, la prevención de la lesión o puesta en peligro se sirve del medio de la pena. En definitiva, el recurso a la pena y sus fines resulta esencial para la configuración de cuáles deben ser los aspectos del hecho y de las circunstancias que le rodean que deben integrar el delito y que pueden variar según los puntos de vista de los que se parta.

Desde esta perspectiva, el rechazo de la categoría de la punibilidad no puede basarse en que se usan la pena y sus fines, puesto que en mayor o menor medida, hasta donde alcanzo a ver, todos lo hacemos en nuestras construcciones. Las diferencias derivan de la función que se atribuya a la pena. En este sentido, allí donde se asigne a la pena la función de realizar un valor, la justicia, no habrá espacio más allá de lo injusto culpable para ulteriores categorías, sea en el delito o fuera de él. En cambio, cuando se parte de una función utilitaria de la pena,

54 Mendes de Carvalho, E.: Punibilidad. Op. Cit., pág. 461. 
la prevención, ya sea del tipo que sea, entonces en el delito se ha de reconocer el aspecto dinámico y prospectivo propio de cualquier teoría relativa. Con la admisión de esta idea, sin embargo, no desembocamos en una concepción unitaria del delito. Y ello porque mientras algunos modelos tratan de configurarlo exclusivamente sobre la base de la prevención, atendiendo solo a la dimensión social de la pena, probablemente la doctrina mayoritaria no acepta este tipo de planteamientos y junto a dicho aspecto social, divisa una esfera individual en dicha sanción derivada de su esencia. La pena es un mal, una privación de bienes esenciales que exige primariamente una justificación de la misma frente al individuo que la va a sufrir. Ello supone que solo si podemos hacer responsable a la persona de la infracción de la norma y en la medida de la misma ${ }^{55}$ podremos plantearnos si el recurso a la pena estaría justificado por su utilidad social. Esto quiere decir que solo y en la medida en que se le pueda atribuir la responsabilidad por la infracción de la norma cabrá utilizarlo para la satisfacción de una finalidad social. Hasta donde alcanzo a ver incluso las teorías absolutas están usando a la persona para la realización de algo que le trasciende. La diferencia se plantearía con aquellas concepciones que pretenden configurar la teoría del delito desde una perspectiva exclusivamente social, es decir, olvidando que la pena, al suponer una privación de bienes esenciales, exige primeramente la justificación frente al que la va a sufrir. Aclarado esto, no se alcanza a comprender donde estaría la lesión de la dignidad de la persona que un sector dela doctrina imputa a quienes admiten la categoría de la punibilidad basada en consideraciones utilitarias. La impunidad o la atenuación de la pena para algunos injustos culpables no viola derecho alguno de la persona.

55 En este sentido, Silva Sánchez, J. M.: "La teoría de la determinación de la pena como sistema (dogmático): un primer esbozo”, en Indret, 2/2007, pág. 5 , indica que "la teoría de la determinación de la pena debe manifestarse, ante todo, como la dimensión cuantitativa (o de grado) de un sistema de la teoría del delito que, por su parte, debería dejar de ser entendido en general como sistema binario". 


\section{El momento constitutivo del delito}

La segunda cuestión que está impidiendo lograr un consenso se refiere a la fijación del momento constitutivo del delito. En efecto, pese al predominio de las teorías relativas, se sigue manteniendo por un importante sector de la doctrina que el delito queda constituido desde el momento en el que se produce la infracción de la norma primaria. Con ello, cualquier aspecto que no exista al tiempo de esta, no podría integrarse en la teoría del delito. En mi opinión, esta conclusión, plenamente coherente con las construcciones del delito elaboradas por las teorías absolutas, no encaja con una opción del Derecho penal orientada a la prevención. Desde la prevención especial, no solo interesaría la infracción del hecho, sino cualquier otra circunstancia, anterior, simultánea o posterior a la infracción de la norma. Piénsese, por ejemplo, en el toxicómano que comete varios robos para conseguir droga y que antes de ser enjuiciado, se somete con éxito a un programa de desintoxicación, consigue un trabajo y deja de cometer hechos delictivos. ¿Cómo un Derecho penal orientado a la prevención especial no va a incluir en sus presupuestos estas circunstancias? Y lo mismo cabe decir desde una teoría orientada a la prevención general. La infracción de la norma, más allá de la lesión o puesta en peligro que trae consigo, despliega unos efectos consistentes en el cuestionamiento de la vigencia de la norma que no constituyen una magnitud estática, sino que pueden desaparecer o atenuarse en función de muy diversas circunstancias (conductas reparadoras de los implicados, comportamientos de colaboración con la Administración de Justicia, transcurso del tiempo, secuelas de la propia infracción sobre el infractor -pena natural-, etc). Si el Derecho penal y sus consecuencias se orientan a la prevención, su presupuesto, el delito, no puede ignorar todas aquellas circunstancias que inciden sobre la misma. Sin embargo, en la doctrina está costando enormemente superar este dogma de las teorías absolutas, siendo así que es difícil de comprender por qué el momento de la constitución de lo injusto, la infracción de la norma primaria, debe fijar la constitución del delito que es un problema de nor- 
ma secundaria donde se trata de fijar bajo qué presupuestos el Derecho penal va a definir la misma como delito de cara a su prevención. Dicho de otro modo, no parece razonable que una parte del delito, el injusto, fije el momento constitutivo del todo, el delito, cuando se reconoce que este contiene elementos que son ajenos a la primera, el injusto, lo que les lleva a sostener la existencia de dos grupos de circunstancias, unas, las existentes al tiempo de la infracción que se integrarían en el delito y otras, que aparecen después, que formarían parte de una categoría no perteneciente al delito, denominadas otros presupuestos de la pena. A ello habría que sumar normalmente las condiciones de procedibilidad y en ocasiones otras circunstancias de la pena. De esta manera, más allá de lo injusto culpable tendríamos tres o cuatro categorías diferentes.

Pero incluso entre los partidarios de la admisión de la punibilidad que rechazan la necesidad de crear una categoría adicional para las circunstancias que se producen después de la infracción de la norma, predomina la idea de que todavía habría otras dos categorías: una que agruparía las circunstancias relativas a la pena y la otra en la que se incluirían los presupuestos procesales. En este sentido, por ejemplo, Díez Ripollés, habla de "los elementos utilitarios de la penalidad" que son aquellos "que tanto en la imposición como en la ejecución de la reacción penal atienden de modo predominante a la necesidad de esa imposición y ejecución", añadiendo que "su estudio es propio de la teoría de la pena. Se encuentran distribuidos entre las reglas de determinación legal y judicial de la pena así como entre las reglas penales y penitenciarias". Dentro de estos elementos distingue tres subgrupos: los relativos a la necesidad de la imposición de la pena; los referentes a la necesidad de la ejecución de la reacción penal y finalmente una buena parte de las denominadas causas de extinción de la responsabilidad criminal ${ }^{56}$. Además de estas circunstancias, Díez Ripollés distingue los "elementos utilitarios de procedibilidad". "Al momento de la verificación

56 Díez Ripollés, J. L: La categoría. Op. Cit., págs. 535 y s. 
de la responsabilidad y reacción penales nos encontramos, junto a reglas que determinan la corrección del procedimiento penal, con otras que atienden a si es necesario llevar a término, o en qué condiciones, el procedimiento penal". En este grupo distingue entre elemento genéricos que afectan a cualquier proceso penal y los específicos que solo entrarían en juego en el procedimiento penal de determinadas figuras delictivas ${ }^{57}$. Así pues, Díez Ripollés distingue tres categorías: punibilidad, elementos utilitarios de la penalidad y elementos utilitarios de la procedibilidad, que tienen idéntico fundamento (consideraciones de eficacia, eficiencia y efectividad) y sin que quede claro si el tratamiento debe ser igual o distinto para cada una de ellas.

Hasta donde alcanzo a ver, también quienes defienden un sistema integral de Derecho penal aceptan la distinción entre elementos de la punibilidad, de la determinación de la pena y elementos procesales ${ }^{58}$. Y ello pese que, al menos en la opinión

57 Ibidem. Págs. 536 y s.

58 Así, Wolter, J.: "Estudio sobre la dogmática y la ordenación de las causas materiales de exclusión, del sobreseimiento del proceso, de la renuncia a la pena y de la atenuación de la misma. Estructuras de un sistema integral que abarque el delito, el proceso penal y la determinación de la pena", en Wolter/ Freund: El sistema integral del Derecho penal. Delito, determinación de la pena y proceso penal. Trad. De Benlloch Petit, Pastor Muñoz, Ragués i Vallés, Robles Planas, Sánchez-Ostiz Gutiérrez y Silva Sánchez. Marcial Pons, Madrid-Barcelona, 2004, págs. 35 y ss., distingue tres niveles en el delito: merecimiento de pena del injusto culpable, necesidad de pena del injusto culpable (responsabilidad) y punibilidad del injusto culpable. Para este autor, el sistema procesal penal y el sistema de determinación de la pena parten, en cambio del dato de que el autor no sólo ha realizado un injusto culpable merecedor y necesitado de pena, sino que, desde consideraciones genéricas de política general, así como desde consideraciones específicas de política jurídico-constitucional y de política jurídico-procesal, se atribuye al Estado un derecho a recurrir a la pena (unido a un deber fundamental de «persecución y castigo»). Frente a esto excepcionalmente cabrá prescindir de la pena -salvaguardando un espacio para el arbitrio judicial" mediante la figura de la «renuncia a la pena», o bien cabrá renunciar a la persecución penal mediante «la renuncia a ejercitar la acción pública»". Por su parte, Freund, G.: "Sobre la función legitimadora de la idea de fin en el sistema integral del Derecho penal", en Wolter/Freund: El sistema. Op. Cit., págs. 93 y ss., señala que el sistema integral del Derecho penal está formado por 
de algunos, en su planteamiento todos los elementos que deciden sobre la aplicación de la norma secundaria serían equivalentes funcionales ${ }^{59}$.

La existencia de varias categorías que responden al mismo fundamento es lo que, a mi juicio, permite la existencia de circunstancias que son funcionalmente equivalentes. Piénsese, por ejemplo, en la idea, muy extendida, de evitar la intervención del Derecho penal cuando algunos delitos contra la propiedad son cometidos por personas unidas por una relación de parentesco a la víctima. La intervención se puede eludir introduciendo una causa de exclusión de la pena o excusa absolutoria, como sucede en nuestro Código penal, art. 268, o bien mediante la exigencia de la previa denuncia del familiar afectado, como acaece en el Código alemán, parágrafo 247. Piénsese en la mediación que en ocasiones aparece como una causa de exclusión o de atenuación de la pena, tal como ha previsto el Código penal alemán en su parágrafo 46a, y en otras como una circunstancia que pone fin anticipadamente al proceso, tal como prevé el art. 19 de la Ley 5/2000, de 12 de enero, reguladora de la responsabilidad penal de los menores, o han suscitado las diversas propuestas de nueva Ley de Enjuiciamiento Criminal. Una reducción de la pena se puede lograr mediante la introducción circunstancias atenuantes en el libro primero o segundo del Código penal o a través de la incorporación de elementos que acortan el tiempo de cumplimiento. El efecto es exactamente el mismo, pero con

el Derecho penal sustantivo, el Derecho de la determinación de la pena y el Derecho procesal penal "como auténtico campo de aplicación de los dos anteriores". Pero esto no le lleva a unificarlos, sino que sigue distinguiendo tres subsistemas dentro del sistema integral del Derecho penal. En efecto, dice este autor anticipando su conclusión que "puede ya afirmarse que no solo se demostrará que el sistema del delito y de la determinación de la pena deben perseguir un mismo fin (o idea de fin), sino, también, que el Derecho procesal no se encuentra al margen de los dos anteriores, sino que es otro subsistema dentro del más amplio sistema integral del Derecho penal".

59 Así lo pone de relieve Silva Sánchez, J. M.: "Introducción: dimensiones de la sistematicidad de la teoría del delito", en Wolter/Freund: El sistema. $O p$. Cit., pág. 23. 
una ventaja para estos últimos, puesto que son más flexibles y dinámicos y permiten adaptarse mejor a la prevención al tener una perspectiva más amplia de la evolución, por ejemplo, de la peligrosidad del sujeto.

A mi juicio, si por algo se caracteriza el Derecho penal moderno es por un desplazamiento hacia la teoría de la pena y su determinación y el proceso penal de las cuestiones que tradicionalmente no han encajado en lo injusto culpable. La teoría del delito solo debe acoger las cuestiones de las que depende el si de la pena, lo que se traduce en un sistema esencialmente binario ${ }^{60}$. Todo lo demás debe ir a la teoría de la pena y su determinación o a los presupuestos del proceso penal. La insuficiencia de lo injusto culpable no ha hecho reconsiderar estas tesis, habiéndose en gran medida conservado un sistema rígido y estático propio de la teoría del delito elaborada por las concepciones absolutas de la pena ${ }^{61}$. Por ello muchas decisiones sobre si se debe aplicar

60 Silva Sánchez, J. M.: La teoría. Op. Cit., pág. 5.

61 En este sentido, destaca Frisch, W.: Pena. Op. Cit., pág. 21, que "Sin embargo, precisamente este es el estado actual de la teoría del delito, en la medida en que ésta, pese a la transición a las teorías de la confirmación de la vigencia de la norma, todavía se sigue aferrando al concepto tradicional, estado que se perpetuaría si se siguiera asiendo de forma amplia a esta concepción del delito, por ejemplo, por "razones pragmáticas". La teoría del delito tradicional ha sido esencialmente desarrollada sobre el fundamento de la teoría de una justa retribución a través de la pena; los requisitos del delito reproducen, pues, las condiciones de una retribución justa: el injusto y la culpabilidad del autor en ese injusto. Tras el desmoronamiento de la teoría de la retribución el pensamiento teórico penal de la compensación de la culpabilidad pasó a desempeñar el papel de dicha teoría. La primera teoría, la de la retribución, con miras al objetivo que se propone, resulta ser altamente problemática; la segunda, la teoría de la compensación de la culpabilidad, adolece, básicamente, de no lograr explicar cómo el injusto culpable en el sentido de un menoscabo del bien jurídico acontecido en el pasado debería poder ser "compensado" a través de la pena. Por eso mismo, han sido con razón ambas concepciones reemplazadas por teorías provenientes de la órbita de la confirmación de la vigencia de la norma a través de la pena. Sin embargo, a diferencia de lo que en gran medida ha sucedido, no es suficiente ahora con vincular simplemente esta (acertada) teoría de la pena con el concepto de delito clásico. A la teoría de la pena que en lo sucesivo se estima como acertada le corresponde su propia y autónoma concepción del delito." 
una pena se han reconducido al proceso penal que ha sabido adaptarse a esta situación sustituyendo el principio de legalidad por el principio de oportunidad. De este modo, una parte de las cuestiones relativas a si se impone una pena $\mathrm{y}$, por supuesto, todas las relativas a la medida de la misma se han desconectado del delito. Frente a ello se ha objetado que el ámbito de la determinación de la pena no puede desligarse del delito, puesto que esta no es más que la cuantificación de este ${ }^{62}$. Pero ello implica que lo que se cuantifica forma parte del delito, lo cual cuestiona una concepción sobre este que no dé cabida a todas las circunstancias relacionadas con el hecho que inciden sobre el fin del Derecho penal, la prevención ${ }^{63}$. Y lo mismo cabe decir respecto de la cada vez mayor incorporación al proceso penal de circunstancias que terminan evitando la imposición de una pena, puesto que sin proceso no cabe imponer esta. $\mathrm{Y}$ en este sentido, el proceso es una condición de aplicación de la pena ${ }^{64}$.

62 Así, por ejemplo, Silva Sánchez, J. M.: Introducción. Op. Cit., pág. 5, señala que "la determinación de la pena es, por encima de otras consideraciones, determinación del exacto contenido delictivo del hecho".

63 En este sentido, Silva Sánchez, J. M.: La teoría. Op. Cit., pág. 8, dice que "el segundo efecto de la sistematización de la teoría de la determinación de la pena sobre la teoría del delito es la necesidad de elaboración categorial en éste más allá de la culpabilidad. En efecto, no pueden existir factores relevantes para la individualización de la pena (comportamientos posteriores al hecho, nivel de sensibilidad a la pena, transcurso del tiempo) que carezcan de un soporte categorial en la teoría del delito. Sin embargo, parece claro que hay múltiples circunstancias del hecho concreto a las que se asigna relevancia cuantificadora y que no tienen una referencia categorial clara."

64 Pastor, D. R.: El plazo razonable en el proceso del Estado de Derecho. Una investigación acerca de la excesiva duración del proceso penal y sus posibles soluciones. Konrad Adenauer Stiftung-Ad Hoc, 2002, pág. 601, en relación al debate sobre la distinción entre los presupuestos procesales y los presupuestos de la pena que están más allá de lo injusto culpable, sostiene que "queda, ante todo, la certeza de que presupuestos procesales y las demás condiciones que fundamentan o excluyen la punibilidad por fuera del injusto culpable no pueden ser distinguidos satisfactoriamente. Esto representa, de modo inexorable, que, en realidad, derecho penal y derecho procesal penal no pueden ser separados y no sólo en este terreno de frontera, sino en todo el ámbito de actuación de ambas ramas del orden jurídico penal. Así, indefectiblemente, el mandato del debido proceso está integrado, en cierta 
Pues bien, como hemos visto, en lugar de agrupar en una categoría todas estas circunstancias que responden a idéntico fundamento y que merecerían un tratamiento unitario, un importante sector de la doctrina distingue tres o cuatro categorías. Al tener el mismo fundamento, estas circunstancias son perfectamente intercambiables, pudiéndose configurar como elementos de unas u otras. Frente a esta situación no cabe responder que de todos modos esto tiene escasa trascendencia. Este sería el caso si el tratamiento de todas ellas fuera el mismo. Sin embargo, ello no es así, pues su ubicación en un ámbito u otro produce diferentes efectos. No es irrelevante, por ejemplo, configurar una circunstancia como un elemento de la punibilidad o de los presupuestos procesales. Mientras el principio de legalidad es de aplicación a los aspectos de la punibilidad ${ }^{65}$, en cambio, se entiende que no rige para las cuestiones procesales ${ }^{66}$. Ciertamente cabría

forma, a toda prohibición penal, pues como la propia Constitución Nacional lo denota (nadie puede ser penado=no es punible) la misma realización del proceso vendría a funcionar como una ¡la i condición objetiva de punibilidad sin cuya presencia la sanción penal resulta inadmisible”. En este sentido, Ragués, R.: "El Sistema Integral del Derecho Penal: variaciones en torno a una ideal", en Revista Eletrônica de Direito Penal e Política Criminal, vol. $5, \mathrm{n}^{\circ} 1,2017$, pág. 11 , indica que "podría tal vez pensarse que, en realidad, la punibilidad y la perseguibilidad no son, por así decirlo, territorios limítrofes entre el Derecho sustantivo y el procesal, sino que la perseguibilidad -y las normas procesales en su conjunto, cuyo cumplimiento es necesario para el efectivo castigo de un delito- debe considerarse un presupuesto de la punibilidad".

65 Así, por ejemplo, García Pérez, O.: La punibilidad. Op. Cit., págs. 393 y ss.; Cocco, G.: La punibilità. Op. Cit., págs. 142 y ss.; Costa Pinto, F. da: A categoría. Op. Cit., págs. 1199 y ss.

66 Así, por ejemplo, Díez Ripollés, J. L.: Derecho penal español. Op. Cit., pág. 73; Kindhäuser, U.: Strafrecht. AT. $6^{\mathrm{a}}$ ed., Nomos, Baden Baden, 2013, págs. 40 y s., Köhler, M.: Strafrecht. AT. Springer, Berlin, Heidelberg, 1997, pág. 97; Fiandaca/Musco: Diritto Penale. Parte Generale. $7^{\mathrm{a}}$ ed., Zanichelli, Bolonia, 2014, pág. 95. Así lo ha reconocido también el TEDH. Cfr., por ejemplo, Sentencia de la Gran Sala de 17 de septiembre de 2009 (nº 2), caso Scoppola v Italia, con más referencias a otras sentencias en el apartado 110. No obstante, matiza que la determinación de la naturaleza del precepto no depende de la ubicación sistemática que tenga en el derecho nacional. Por ello, pese a tratarse de un precepto de la Ley procesal penal, llegó en este 
objetar que en todo caso lo que habría que hacer es ofrecer el mismo tratamiento a todas las circunstancias con independencia de la categoría en la que se sitúen. Sin embargo, esto tampoco es satisfactorio, puesto que la unidad de fundamento y tratamiento es lo que identifica la existencia de una categoría, por lo que no sería admisible la defensa de varias.

Por ello, en mi opinión, no es deseable que más allá de lo injusto culpable situemos tantas o más que antes. La consecuencia de este planteamiento es que el legislador puede elegir si aplica, o no, algunas de las garantías que rigen el Derecho penal como el principio de legalidad. Para ello basta con incluir una circunstancia en el Código penal bajo el ropaje de una causa que excluye la pena o en las leyes procesales con la apariencia de una condición de procedibilidad. Y algo parecido acontece con las circunstancias atenuantes y aquellas que reducen el tiempo de cumplimiento ${ }^{67}$.

Por lo demás, no se puede restar trascendencia a estas cuestiones aludiendo a que estamos hablando de un grupo reducido de circunstancias y, por tanto, de escasa trascendencia prác-

caso a la conclusión de que se trataba de un precepto de naturaleza material porque afectaba a la gravedad de la sanción a imponer en un proceso abreviado (art. 442 de la Ley procesal italiana).

67 El Tribunal Constitucional, en su Sentencia 39/2012, Sección 1a , de 29 de marzo de 2012 (Ponente Elisa Pérez Vera), ha señalado, apoyándose en la jurisprudencia del Tribunal Europeo de Derechos, que "que las cuestiones relativas a la ejecución de la pena y no a la propia pena, en la medida en que no impliquen que la pena impuesta sea más grave que la prevista por la ley, no conciernen al derecho a la legalidad penal consagrado en el art. 7.1 del Convenio Europeo de Derechos Humanos, aunque sí pueden afectar al derecho a la libertad". En efecto, el TEDH ha venido sosteniendo que una cosa es la pena y otra distinta su ejecución, siendo la consecuencia principal de esta distinción que las cuestiones relativas a la segunda no están sujetas al principio de legalidad. Así, por ejemplo, lo dijo en su Sentencia de la $1^{\mathrm{a}}$ Sección, caso Grava contra Italia, de 10 de julio de 2003, apartados 42 y ss. No obstante, esta posición la ha matizado un poco la Sentencia de la Gran Sala, caso Kafkaris contra Chipre, de 12 de febrero de 2008, apartados 146 y 152. La matización es todavía más evidente en la Sentencia de la Gran Sala, de 21 de octubre de 2013, apartados 85 y ss. 
tica. En realidad, hay que tener presente que ya hay elementos que son de aplicación general y que se aplican con bastante frecuencia en la práctica como son las atenuantes de reparación del daño o de confesión del hecho. También el desistimiento de la tentativa es de aplicación general. Pero es que, además, no cabe olvidar que estos supuestos cada vez proliferan más en la justicia penal. Piénsese, por ejemplo, en la pena natural, la mediación y otras circunstancias que los textos legales están amparando bajo el manto del denominado principio de oportunidad o incluso de cuestiones que afectan a la ejecución. Con ello nos encontramos ante un escenario en el que bastantes injustos culpables dejarían de castigarse por la falta de necesidad de prevención. Y hay que destacar otro aspecto que, a mi juicio, sería necesario tener presente. El reconocimiento del planteamiento tradicional nos conduce a recortar el papel del Derecho penal, pues aunque este ha elaborado los principios que deben regir la intervención penal, en la actualidad su función se circunscribe a la selección de las normas cuya infracción va a constituir un ilícito penal. La discusión sobre la despenalización que hay que abordar frente a la multiplicación de los tipos penales en los Códigos es algo que queda al margen del Derecho penal pese a que ello debería acometerse desde la óptica de los principios elaborados en su seno. En efecto, en no pocas ocasiones el protagonismo lo tiene un sector del ordenamiento que consideramos como algo diferente al Derecho penal, el del Derecho procesal penal, lo cual puede llevar a la exclusión de aquel de uno de los grandes debates actuales, el de la búsqueda de recursos alternativos a la pena para despenalizar $^{68}$.

68 Piénsese, por ejemplo, en el Anteproyecto de Ley de Enjuiciamiento Criminal de 2011en el que se preveía la introducción del principio de oportunidad. En su art. 148.1 establecía que "El procedimiento penal podrá concluir por razones de oportunidad cuando la imposición de la pena resulte innecesaria o contraproducente a los fines de prevención que constituyen su fundamento". En el art. 149.1 se disponía lo siguiente: "1. Para todo tipo de faltas y para los delitos castigados con penas de prisión de hasta dos años, con multa cualquiera que sea su extensión, o con privación de derechos que no exceda 


\section{Bibliografía}

ARROYO ZAPATERO, L.:" Derecho penal económico y Constitución”, en Revista Penal, $\mathrm{n}^{\circ} 1$, págs. 3 y ss.

BITTAR, W. B.: A punibilidade no direito penal. Almedina, 2015.

BUSTOS RUBIO, M.: "Más allá del injusto culpable los presupuestos de la punibilidad", en Estudios penales y criminológicos, $\mathrm{n}^{\mathrm{o}} .35,2015$, págs. 189 y ss.

COCCO, G.: La punibilità.Cuarto elemento del reato. Wolters Kluwer-Cedam, Milán, 2017.

COSTA PINTO, F. da: A categoria da punibilidade na teoria do crime. 2 vols., ed. Almedina, Coimbra, 2013.

CUELLO CONTRERAS/MAPELLI CAFFARENA: Curso de Derecho penal. Parte General. Reimpresión de la $3^{\mathrm{a}}$ ed. Tecnos, Madrid, 2016.

CUERDA ARNAU, M. L.: "Aproximación al principio de proporcionalidad en Derecho penal", en Estudios jurídicos en memoria del profesor Dr. D. José Ramón Casabó Ruiz. T. I. Valencia, 1997, págs. 447 y ss.

de diez años, el fiscal podrá decretar el archivo total o parcial de la investigación siempre que:

a) La incidencia del hecho punible sobre los bienes o intereses legalmente protegidos resulte mínima o insignificante, dado el tiempo transcurrido desde la comisión de la infracción o las circunstancias en las que ésta se produjo.

b) Pueda reputarse mínima la culpabilidad del responsable, de forma que la imposición de la pena no haya de reportar ninguna utilidad pública.

c) La comisión de la infracción haya causado a su autor un perjuicio grave que haga innecesaria o manifiestamente desproporcionada la imposición de una pena". Y más adelante en el art. 150 se preveían los supuestos en los que se suspendía el proceso que finalmente podría desembocar en un sobreseimiento. Por destacar solo algunos de los supuestos en los que se permitía poner fin al proceso. Como se puede ver, no es difícil llegar a la conclusión de que esto no es una mera cuestión de realización del Derecho penal sino de fijación del alcance de este, pero insertado en algo que se define como un cuerpo extraño a este sector del ordenamiento, el del Derecho procesal penal. En mi opinión, a ello nos ha llevado la falta de reconocimiento de un aspecto dinámico en la teoría jurídica del delito. 
DÍEZ RIPOLLÉS, J. L.: Derecho penal español. Parte General. Tirant lo Blanch, Valencia, 2016.

DÍEZ RIPOLLÉS, J. L.: "La categoría de la punibilidad en el Derecho penal español", en Estudios de Derecho penal. Homenaje al profesor Santiago Mir Puig. IBdeF, Montevideo-Buenos Aires, 2017, págs. 523 y ss.

ENGISCH, KARL: Auf der Suche nach der Gerechtigkeit. R. Piper, Munich, 1971.

FARALDO CABANA, P.: Las causas de levantamiento de la pena. Tirant lo Blanch, Valencia, 2000.

FERRÉ OLIVÉ, J. C.: "Punibilidad y proceso penal”, en Revista General de Derecho penal, 10, 2008, págs. 1 y ss.

FIANDACA/MUSCO: Diritto Penale. Parte Generale. $7^{\mathrm{a}}$ ed., Zanichelli, Bolonia, 2014.

FREUND, G.: "Sobre la función legitimadora de la idea de fin en el sistema integral del Derecho penal", en Wolter/ Freund: El sistema integral del Derecho penal. Delito, determinación de la pena y proceso penal. Trad. De Benlloch Petit, Pastor Muñoz, Ragués i Vallés, Robles Planas, Sánchez-Ostiz Gutiérrez y Silva Sánchez. Marcial Pons, Madrid-Barcelona, 2004, págs. 91 y ss.

FRISCH, W.: "Pena, delito y sistema del delito en transformación", en Indret, 3/2014 (trad. de Ivó Coca Vila), págs. 1 y ss.

GALLAS, W.: Beiträge zum Verbrechenslehre. Walter de Gruyter, Berlin, 1968, págs. 1 y ss.

GARCÍA PÉREZ, O.: La punibilidad en el Derecho penal. Aranzadi, Pamplona, 1997.

GARCÍA PÉREZ, O.: "La racionalidad de la proporcionalidad en sistemas orientados a la prevención especial", en $R e$ vista electrónica de ciencia penal y criminología, $\mathrm{n}^{\mathrm{0}} 9$, 2007, págs. 1 y ss.

GIL GIL/LACRUZ LÓPEZ/MELENDO PARDOS/NÚÑEZ FERNÁNDEZ: Sistema de responsabilidad penal. Dykinson, Madrid, 2017. 
GÜNTHER, H. L.: Strafrechtswidrigkeit und Strafunrechtsausschluß. Carl Heymann, Köln-Berlin-Bonn-München, 1983.

JAKOBS, G.: Strafrecht. AT. $2^{\mathrm{a}}$ ed. Walter de Gruyter, BerlinNew York, 1991.

KINDHÄUSER, U.: Strafrecht. AT. $6^{\mathrm{a}}$ ed., Nomos, Baden Baden, 2013.

KÖHLER, M.: Strafrecht. AT. Springer, Berlin, Heidelberg, 1997. https://doi.org/10.1007/978-3-642-59157-0.

LISZT, F. VON: Tratado de Derecho penal. T. II. Trad. de L. Jiménez de Asúa y anotaciones de Quintiliano Saldaña. Reus, Madrid, sin fecha.

LISZT, F. VON: Strafrechtliche Vorträge und Aufsätze. T. I. Reimpresión de la edición de 1905, Walter de Gruyter, Berlin, 1970.

LUZÓN PEÑA, D. M.: "Causas de atipicidad y causas de justificación", en Causas de Justificación y de atipicidad en Derecho penal. Aranzadi, Pamplona, 1995, págs. 21 y ss.

LUZÓN PEÑA, D. M.: Voz "Punibilidad", en Enciclopedia jurídica básica. Vol. IV. Civitas, Madrid, 1995, págs. 5423.

LUZÓN PEÑA, D. M.: Lecciones de Derecho penal. Parte General. $3^{\text {a }}$ ed. Tirant lo Blanch, Valencia, 2016.

MANJÓN-CABEZA OLMEDA, A.: Las excusas absolutorias del derecho español (doctrina y jurisprudencia). Tirant lo Blanch, Valencia, 2014. DOCUMENTO TOL4.705.027

MAQUEDA ABREU, M. L. Y LAURENZO COPELLO, P.: El Derecho penal en casos. Parte General. Teoría y Práctica. Tirant lo Blanch, Valencia, 2016.

MARINUCCI/DOLCINI/GATTA: Manuale de Diritto Penale. Parte Generale. $7^{\mathrm{a}}$ ed. Giuffrè, Milán, 2018.

MENDES DE CARVALHO, E.: Punibilidad y delito. Reus, Madrid, 2007.

MORILlaS CUEVA, L.: Sistema de Derecho penal. Parte General. Dykinson, Madrid, 2018.

MÜLLER-DIETZ, H.: "Integrationsprävention und Strafrecht: zum positiven Aspekt der Generalprävention", en Fest- 
schrift für Hans-Heinrich Jescheck zum 70. Geburtstag. T. II. Duncker \& Humblot, Berlin 1985, págs. 813 y ss. MUÑOZ CONDE, F.: Introducción al Derecho penal. Bosch, Barcelona, 1975.

NÚÑEZ J.: "Algunas reflexiones sobre la punibilidad en el tratamiento jurídico penal del terrorismo", en Gil Gil/Maculan: La influencia de las víctimas en el tratamiento jurídico de la violencia colectiva. Dykinson, Madrid, 2017, págs. 243 y ss.

ORTS BERENGUER/GONZÁLEZ CUSSAC: Compendio de Derecho Penal. Parte General. $4^{\text {a }}$ ed. Tirant lo Blanch, Valencia, 2014.

PASTOR, D. R.: El plazo razonable en el proceso del Estado de Derecho. Una investigación acerca de la excesiva duración del proceso penal y sus posibles soluciones. Konrad Adenauer Stiftung-Ad Hoc, 2002.

PÉREZ FERRER, F.: El desistimiento voluntario de la tentativa en el Código penal español. Dykinson, Madrid, 2008.

PORTILLA CONTRERAS, G.: "El principio de intervención mínima y bienes jurídicos colectivos", en $C P C \mathrm{n}^{\circ} 39$, 1989, págs. 723 y ss.

POZUELO PÉREZ, L.: El desistimiento en la tentativa y la conducta postdelitiva. Tirant, valencia, 2003.

RADBRUCH, G.: "Zur Systematik der Verbrechenslehre", en Festgabe für Reinhard Frank. T. I. J. C. B. Mohr, Tübingen, 1930, págs. 158 y ss.

RAGUÉS, R.: "El Sistema Integral del Derecho Penal: variaciones en torno a una ideal", en Revista Eletrônica de Direito Penal e Política Criminal, vol. 5, nº 1, 2017, págs. 1 y ss.

ROXIN, C.: Politica criminal y sistema del Derecho penal. Trad. de F. Muñoz Conde. Bosch, Barcelona, 1972.

ROXIN, C.: Problemas básicos del Derecho penal. Trad. de D. M. Luzón Peña. Reus, Madrid, 1976.

ROXIN, C.: Strafrecht. AT. $3^{\text {a }}$ ed. C. H. Beck, München, 1997.

SÁNCHEZ-OSTIZ, P.: "Una aportación al estudio de la punibilidad. A propósito de la autodenuncia tras el fraude fis- 
cal", en Urquizo Olaechea/Abanto Vásquez/Salazar Sánchez: Dogmática del Derecho penal económico y política criminal. Homenaje a Klaus Tiedemann. Vol. I. Universidad de San Martín Porres, Lima, 2011, págs. 675 y ss.

SCHMIDHÄUSER, E.: Strafrecht. AT. J. C. B. Mohr, Tübingen, 1970.

SCHMIDHÄUSER, E.: "Über einige Begriffe der teleologischen Straftatlehre", en $J u S, 1987$, págs. 373 y ss.

SILVA SÁNCHEZ, J. M.: "Introducción: dimensiones de la sistematicidad de la teoría del delito", en Wolter/Freund: El sistema integral del Derecho penal. Delito, determinación de la pena y proceso penal. Trad. De Benlloch Petit, Pastor Muñoz, Ragués i Vallés, Robles Planas, Sánchez-Ostiz Gutiérrez y Silva Sánchez. Marcial Pons, Madrid-Barcelona, 2004, págs. 15 y ss.

SILVA SÁNCHEZ, J. M.: "La teoría de la determinación de la pena como sistema (dogmático): un primer esbozo", en Indret, 2/2007, págs. 1 y ss.

VICENTE REMESAL, J. de: El comportamiento postdelictivo. Universidad de León, 1985.

WOLTER, J.: "Estudio sobre la dogmática y la ordenación de las causas materiales de exclusión, del sobreseimiento del proceso, de la renuncia a la pena y de la atenuación de la misma. Estructuras de un sistema integral que abarque el delito, el proceso penal y la determinación de la pena", en Wolter/Freund: El sistema integral del Derecho penal. Delito, determinación de la pena y proceso penal. Trad. De Benlloch Petit, Pastor Muñoz, Ragués i Vallés, Robles Planas, Sánchez-Ostiz Gutiérrez y Silva Sánchez. Marcial Pons, Madrid-Barcelona, 2004, págs. 31 y ss. 